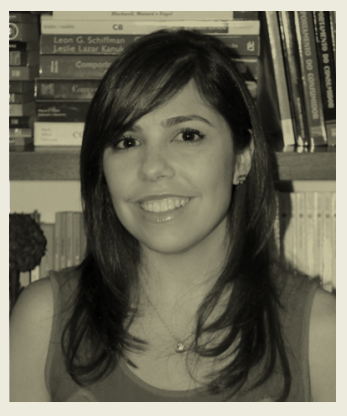

\title{
O NOVO NORMAL E AS \\ MUDANÇAS COMPORTAMENTAIS DO CONSUMIDOR
}

A pandemia da Covid-19 tem provocado uma série de mudanças no estilo de vida e nos hábitos dos consumidores. Diversos países adotaram o isolamento social como medida de controle e prevenção da propagação do novo coronavírus. Uma das respostas do mercado consumidor a isso foi o aumento significativo do consumo digital, o que envolve desde a aquisição de bens físicos via plataformas de marketplace, como Amazon, até serviços de streaming, como Netflix. Isolado em casa, o consumidor fortaleceu o e-business global e local, diversificando as categorias procuradas para compra no e-commerce (alimentos, brinquedos, roupas) e o consumo de produtos digitais (filmes, aplicativos, e-books).

Nos setores educacional e de saúde, a transformação causada pela pandemia foi radical, levando centenas de milhares de estudantes a aderir ao ensino online, assim como pacientes a serem atendidos virtualmente via telemedicina. A tecnologia também passou a ocupar espaço central na vida das pessoas como forma de entretenimento, tendo em vista a disseminação dos happy hours virtuais e o sucesso das lives (isto é, a transmissão de shows online ao vivo). Do mesmo modo, os hábitos alimentares das famílias sofreram transformações decorrentes do isolamento social, pois muitos consumidores passaram a cozinhar mais em casa, usando inclusive as redes sociais como apoio na preparação dos alimentos. As mudanças comportamentais dos indivíduos durante o período da pandemia e, consequentemente, de suas práticas de consumo são inúmeras e repercutem econômica e socialmente de maneira profunda.

Algumas dessas mudanças de comportamento têm impacto especialmente crítico no bem-estar da coletividade. Manter o distanciamento social e lavar as mãos com maior frequência são consideradas práticas essenciais para conter o surto do novo coronavírus e, por isso, tornaram-se responsabilidades compartilhadas, ou seja, hábitos que os consumidores precisaram incorporar em suas rotinas em prol da segurança e do bem-estar coletivo. Nesse processo, as pessoas foram levadas a ressignificar os símbolos de consumo e de socialização: o uso de álcool em gel e de máscaras em público traduziu-se em respeito pelo outro, enquanto o cumprimento por aperto de mão foi substituído por acenos e gestos que não envolvem toque. As marcas, por sua vez, têm tentado dialogar constantemente com essas mudanças, como o Mercado Livre, que trocou temporariamente sua identidade visual com a imagem de mãos dadas para a de saudação com cotovelos.

Outro ponto a se salientar é que o novo coronavírus evidenciou problemas de saúde enraizados em questões comportamentais que existiam muito antes da pandemia. Por exemplo, a obesidade, considerada uma epidemia em diversas partes do mundo, tem sido associada ao risco de complicações decorrentes da Covid-19, de modo que a alimentação saudável e a prática da atividade física se apresentam como fatores comportamentais de prevenção.

Por ser uma crise sem precedentes, fica a pergunta: qual será a herança comportamental que a pandemia nos deixará? O comportamento do consumidor moldou-se ao que se convencionou chamar de novo normal, com regras de conduta e de etiqueta próprias e novos hábitos de consumo. Resta saber quais mudanças comportamentais decorrentes da pandemia sobreviverão e como continuarão moldando as respostas dos consumidores no futuro. 